OPEN ACCESS

Edited by:

Gero Benckiser,

Justus Liebig Universität Gießen,

Germany

Reviewed by:

Javier Plasencia,

National Autonomous University

of Mexico, Mexico

Michael Rothballer,

Helmholtz Center Munich, Germany

*Correspondence:

Tehmina Anjum

tehminaanjum@yahoo.com

Specialty section:

This article was submitted to

Plant Microbe Interactions,

a section of the journal

Frontiers in Plant Science

Received: 19 January 2017

Accepted: 08 May 2017

Published: 31 May 2017

Citation:

Fatima S and Anjum T (2017)

Identification of a Potential ISR

Determinant from Pseudomonas aeruginosa PM12 against Fusarium

Wilt in Tomato.

Front. Plant Sci. 8:848

doi: 10.3389/fpls.2017.00848

\section{Identification of a Potential ISR Determinant from Pseudomonas aeruginosa PM12 against Fusarium Wilt in Tomato}

\author{
Sabin Fatima and Tehmina Anjum* \\ Institute of Agricultural Sciences, University of the Punjab, Lahore, Pakistan
}

Biocontrol of plant diseases through induction of systemic resistance is an environmental friendly substitute to chemicals in crop protection measures. Different biotic and abiotic elicitors can trigger the plant for induced resistance. Present study was designed to explore the potential of Pseudomonas aeruginosa PM12 in inducing systemic resistance in tomato against Fusarium wilt. Initially the bioactive compound, responsible for ISR, was separated and identified from extracellular filtrate of $P$. aeruginosa PM12. After that purification and characterization of the bacterial crude extracts was carried out through a series of organic solvents. The fractions exhibiting ISR activity were further divided into sub-fractions through column chromatography. Sub fraction showing maximum ISR activity was subjected to Gas chromatography/mass spectrometry for the identification of compounds. Analytical result showed three compounds in the ISR active sub-fraction viz: 3-hydroxy-5-methoxy benzene methanol (HMB), eugenol and tyrosine. Subsequent bioassays proved that HMB is the potential ISR determinant that significantly ameliorated Fusarium wilt of tomato when applied as soil drench method at the rate of $10 \mathrm{mM}$. In the next step of this study, GC-MS analysis was performed to detect changes induced in primary and secondary metabolites of tomato plants by the ISR determinant. Plants were treated with $\mathrm{HMB}$ and Fusarium oxysporum in different combinations showing intensive re- modulations in defense related pathways. This work concludes that $\mathrm{HMB}$ is the potential elicitor involved in dynamic reprogramming of plant pathways which functionally contributes in defense responses. Furthermore the use of biocontrol agents as natural enemies of soil borne pathogens besides enhancing production potential of crop can provide a complementary tactic for sustainable integrated pest management.

\footnotetext{
Keywords: Fusarium wilt, tomato, induced systemic resistance, Pseudomonas, 3-hydroxy-5-methoxy benzene methanol
}

\section{INTRODUCTION}

Tomato (Solanum lycopersicum L.) is a member of family Solanaceae, cultivated worldwide, ranked first among the processing crops and second as a vegetable crop. In Pakistan it is cultivated on about 58.196 thousand hectares with an annual production of 574.052 thousand tons (FAO, 2013). It contains valuable nutrients like vitamin $\mathrm{A}$ and $\mathrm{C}$, calcium, phosphorus, potassium and magnesium 
(United States Department of Agriculture [USDA], 2009). It is also a source of an antioxidant compound named lycopene that has been found helpful against cancer (Miller et al., 2002). Tomato wilt caused by the fungus Fusarium oxysporum Schlecht. f. sp. lycopersici (Sacc.) W.C. Snyder et H.N. Hansen (FOL) is an alarming disease, causing yield losses up to 25\% (Fravel et al., 2005; Park et al., 2013). Disease control strategies include use of resistant tomato varieties with cultural, chemical and biological control (Agrios, 2005; Pottorf, 2006). Cultural control lost its effectiveness as pathogen has a wide host range. Use of resistant varieties is futile due to chances of mutation in Fusarium spp. Chemical control is now losing its ground due to adverse effects of chemicals on environment and soil microbiota that calls for alternative inputs with lower dependency on chemicals for sustainable agriculture (Lucas, 2011). Recently used biological control employed induced systemic resistance (ISR) mechanism using rhizospheric plant growth-promoting bacteria against fungal pathogens (Pieterse et al., 2014).

Plants are devoid of an immune system which is the chief characteristic of mammals. To deal with different types of pathogens, plants have weakly inducible or constitutive defense systems including plant cell walls, cuticles, phytoanticipins (Underwood, 2012; Newman et al., 2013) and inducible defenses in which plants activate their immune system by the stimulus of signal molecules known as elicitors (Henry et al., 2012; Maffei et al., 2012; Newman et al., 2013). Elicitors can be derived from natural/living organisms like plants and microbes or generated synthetically (Walters et al., 2013).

Plant pathogens stimulate the host plant to activate defense responses against the invaders but this weak defense reaction will not limit the spread of the pathogen into the host plant (Thordal-Christensen, 2003). However, the defense responses can be enhanced by triggering the plant before pathogen attack. Interaction of some rhizobacteria with the plant roots has proven to increase plant resistance against some pathogenic bacteria, fungi and viruses. This phenomenon is termed as ISR (Lugtenberg and Kamilova, 2009). Application of microorganisms to control diseases, which is a form of biological control, is an environment-friendly approach (Lugtenberg and Kamilova, 2009). The direct mechanism of PGPR in biocontrol involves antagonism to soil borne pathogens (Supplementary Data Sheet 1) and indirect mechanism depends on induction of systemic resistance (Choudhary, 2011; Glick, 2012). Generally competition for nutrients, niche exclusion, ISR and antifungal metabolites production are some of the chief modes of biocontrol activity in PGPR (Lugtenberg and Kamilova, 2009). Many rhizobacteria have been reported to produce antifungal metabolites like hydrogen cyanide (HCN), phenazines, pyrrolnitrin, 2, 4-diacetylphloroglucinol, pyoluteorin, viscosinamide, and tensin (Bhattacharyya and Jha, 2012). In 2009, De Vleesschauwer and Höfte (2009) coined the term ISR for resistance induced by PGPR which was found to be independent of the pathway involved.

In case of microbially induced resistance the best option is the use of plant growth promoting rhizobacteria (PGPR) as potential elicitors of plant defense mechanisms (Liu et al., 1995). On the onset of plant colonization by the rhizobacteria, metabolic changes may occur in the host, i.e., production of phytoalexins (Van Peer et al., 1991), accumulation of pathogenesis related (PR) Proteins (Zdor and Anderson, 1992) or deposition of structural barriers, etc. (Benhamou et al., 1996a,b).

Origin of elicitor compounds may be biological (plant or microbe derived) or synthetic like beta-amino-butyric acid (BABA), cis-jasmone and acibenzolar-S-methyl (ASM) (Walters et al., 2013). Plants generally recognize three types of chemical elicitors viz; microbe-associated molecular patterns (MAMPs) derived from beneficial microbes, pathogen-associated molecular patterns (PAMPs) released by pathogenic microbes and damageassociated molecular patterns (DAMPs) produced by plants on injury by insects or herbivores or even during microbial degradation (Henry et al., 2012; Newman et al., 2013). These aforementioned molecules are called "patterns that elicit immunity" (PEIs) which are recognized by plants through transmembrane pattern recognition receptors (PRRs) (Jones and Dangl, 2006; Maffei et al., 2012; Newman et al., 2013). After recognition of MAMPs or DAMPs elicitors pattern-triggered immunity (PTI) is activated in plants. This stimulation of defense reaction restricts the pathogen making plant resistant to additional pathogen attack through the mechanism of induction of systemic resistance (Henry et al., 2012).

Bacteria belonging to the genus Pseudomonas involve pathogen inhibition via competition and/or antagonism (Haas and Défago, 2005) and by developing direct interactions with the host plants through ISR (Bakker et al., 2007). Pseudomonas aeruginosa PM12, used in this study was isolated from healthy tomato roots from vegetable garden of University of the Punjab, Lahore, Pakistan (Fatima and Anjum, 2016). It was characterized on molecular grounds through sequencing of $16 \mathrm{~S}$ rRNA (900bp) and alignment at GeneBank (NCBI, MaryLand), allotted accession number KT966743 (Fatima and Anjum, 2017).

Induced systemic resistance is involved in synthesis of enhanced levels of various secondary metabolites engaged in plant defense mechanisms. These include phytoalexins that increase plant resistance through their toxic action against pathogens. Phytoalexins, i.e., sesquiterpenoids are synthesized by the members of Solanaceae and isoflavonoids are produced in individuals of the Papilionaceae. They inhibit germination of fungal spores and retard fungal growth. Plant tissues exhibiting ISR show increased activity of phenylalanine ammonia lyase (PAL) that leads to resistance response in plants (Verhagen et al., 2010).

Metabolomics is one of the most rapidly growing areas of contemporary science. This technology is now being used to route out reprograming and metabolic fluctuations in plant pathways (De Vos et al., 2007; Zhao et al., 2015). Current investigation revealed that compatible host pathogen interactions are characterized by a lower level of certain defense-related mechanisms compared with host pathogen interactions in the presence of bacterial ISR elicitor that leads to a more dynamic metabolic response over the course of colonization. Furthermore, our results demonstrate that elicitor (HMB) from $P$. aeruginosa (PM12) induces production of secondary metabolites involved in defense pathways of tested plant. 


\section{MATERIALS AND METHODS}

\section{Fungal and Bacterial Strains}

Virulent strain of F. oxysporum isolated from diseased tomato plants growing in vegetable garden of University of the Punjab, Lahore was cultured on potato dextrose agar (PDA difco) for 10 days. Conidia were harvested by gentle scraping in sterile water and pathogen inoculum was prepared by adjusting the concentration to $10^{5} \mathrm{conidia} / \mathrm{ml}$ using haemocytometer. $P$. aeruginosa (PM12) was grown on LB broth medium $(100 \mathrm{ml})$ for $24 \mathrm{~h}$ at $35^{\circ} \mathrm{C}$. For collecting extracellular metabolites culture was pelleted by centrifugation at $4000 \mathrm{~g}$ for $15 \mathrm{~min}$, and the supernatant obtained was processed for ISR assay. Intracellular metabolites were extracted using sonication. Bacterial cell lysis was performed six times through sonication at resonance amplitude for $15 \mathrm{~s}$ at $4^{\circ} \mathrm{C}$.

\section{Preliminary Screening of ISR Determinants from $P$. aeruginosa PM12}

This study was performed to identify the involvement of intracellular metabolites and cell-free culture filtrates (CFCF) of $P$. aeruginosa for inducing systemic resistance against fungal wilt in tomato. Two-weeks old seedlings of Fusarium wilt susceptible tomato variety "Rio-Grande" seeded in sterilized pot media. In total, $50 \mathrm{ml}$ of both extracts (intracellular and extracellular) were supplied to the allocated plastic pots containing $0.5 \mathrm{~kg}$ sterilized soil and after a period of 3 days these pots were inoculated with $50 \mathrm{ml}$ of pathogen @ $10^{5} \mathrm{conidia} / \mathrm{ml}$. Positive control consisted of $P$. aeruginosa PM12 suspension made in water by adjusting the concentration to $10^{4} \mathrm{cfu} / \mathrm{ml}$. Fifty milli liter of sterile distilled water was provided to the pots designated as untreated control. All the pots were incubated for 14 days under greenhouse conditions. There were ten replicates against each treatment and experiment was conducted twice. To determine the disease index (DI), wilting was scored based on the criteria developed by Epp (1987) $(0=$ no wilt symptoms; $1=$ less than $25 \%$ of the plant turned yellow; 2 = yellowing and browning covered nearly $50 \%$ of plant; 3 = whole plant turned brown and died). The equation described by Cachinero et al., 2002 was used to calculate the DI.

$$
\mathrm{DI}=[(\Sigma \mathrm{ni} \times \mathrm{si}) /(\mathrm{N} \times \mathrm{S})] \times 100
$$

where, $\mathrm{ni}=$ the number of tomato plants with wilt symptoms, $\mathrm{si}=$ value of the symptom score, $\mathrm{N}=$ the total number of tested plants, and $\mathrm{S}=$ the highest value of the symptom score.

\section{Isolation of Bioactive Compound(s) from Extracellular Metabolites of $P$. aeruginosa (PM12)}

Methodology proposed by Sumayo et al. (2013) was used to isolate bioactive compound (s) from extracellular metabolites of $P$. aeruginosa (PM12). Extracellular metabolites of $P$. aeruginosa PM12 were obtained as described previously and extracted twice with double volumes of organic solvents such as ethyl acetate, chloroform, n-hexane and $\mathrm{n}$ butanol. All the organic extracts were dried in a rotary evaporator at $50^{\circ} \mathrm{C}$, mixed in $10 \%$ DMSO and subjected to ISR experimentation.

\section{Primary Screening of Bacterial Metabolites Extracted with Various Solvents for ISR Activity}

Seeds of the variety "Rio-Grande" were sown in sterilized media and after 2 weeks of emergence seedlings were transplanted in plastic pots (4 inches diameter) containing sterilized sandy loam soil. Pots were subjected to pathogen inoculum and bacterial metabolites extracted with various organic solvents for each solvent separately. After 1 week of incubation data regarding the disease development was recorded and the solvent treatment found most suitable for the disease reduction was further screened for ISR determinant/s.

\section{Column Chromatography of the Active Metabolites and Selection of Sub Fraction Involved in ISR}

Bacterial metabolite exhibiting highest ISR activity was further fractioned through silica gel column chromatography. Column was washed with double volumes of methanol and ethyl acetate. The extract was fractioned using stepwise elution method with increased concentration of methanol in ethyl acetate. Obtained eluates were evaporated and mixed in 10\% DMSO and checked for ISR activity in a test tube assay. Negative control received pathogen inoculum with $10 \%$ DMSO. Seeds of the variety "RioGrande" were surface sterilized with $1 \% \mathrm{NaOCl}$ and sown in culture tubes containing Murashige and Skoog (MS) medium. Tubes were incubated in a growth chamber at $25^{\circ} \mathrm{C}$ for seedling development. Seedlings were then provided with different bioactive fractions for ISR activity separately. After 2 days of seedlings treatment, $10 \mu \mathrm{l}$ of pathogen inoculum was provided to each tube@10 5 condia/ml. After 1 week of incubation data was recorded regarding DI. Experiment was repeated twice and there were ten replicates for each treatment.

\section{Identification of ISR Determinant(s) by GC-MS Analysis}

Induced systemic resistance active sub-fraction obtained from silica gel chromatography was further subjected to instrumental analysis for identification of potential ISR determinant/s. This study was executed in Agilent GC/MS apparatus including capillary column $(0.25 \mathrm{ID} \times 30 \mathrm{M} \times 0.25 \mu \mathrm{M}$ film thicknesses $)$ in which electron ionization was used as ion source. Helium with flow rate of $1.0 \mathrm{ml} / \mathrm{min}$ was supplied as carrier gas. Column temperature of apparatus was maintained at $30^{\circ} \mathrm{C}$ for $3 \mathrm{~min}$ which was increased at $50^{\circ} \mathrm{C} / \mathrm{min}$ to $180^{\circ} \mathrm{C}$ and by $40^{\circ} \mathrm{C} / \mathrm{min}$ to $200^{\circ} \mathrm{C}$.

\section{ISR Bioassay with Pure Compounds}

Another independent experiment was performed to screen ISR active biochemicals from $P$. aeruginosa. Biochemicals found in ISR active sub-fraction were purchased from the market. Three concentrations, i.e., $0.1,1.0$ and $10 \mathrm{mM}$ of each of the pure biochemicals were applied as soil drench method, application of inoculum (bacterial/pathogen origin) to the soil surrounding 
the roots of transplanted seedlings of tomatoes, at the rate of $50 \mathrm{ml} /$ pot (Algam et al., 2005). Data regarding DI was taken as described earlier after 15 days of treatment applications.

\section{Analysis of Metabolite Profile of Tomato Plants in the Presence of ISR Elicitor from $P$. aeruginosa PM12}

It was found in the previous experiment that HMB acted as the most active compound involved in elicitation of ISR in tested tomato plants therefore another independent experiment was carried out to study metabolic transitions brought about in the tomato plants under the influence of HMB elicitor.

\section{Plant Growth and Inoculation}

Seedlings of the tomato variety 'Rio-Grande' were raised in sterilized sandy loam soil media. After 3 weeks of emergence seedlings were transplanted @ 1 seedling/ pot in plastic pots (4 inches diameter) containing sterilized sandy loam soil. Four treatments were made in this experiment viz; $\mathrm{T} 1=$ Plants receiving ISR elicitor $(\mathrm{HMB})+\mathrm{FOL}, \mathrm{T} 2=$ Plant receiving ISR elicitor $(\mathrm{HMB})$ alone, $\mathrm{T} 3=$ Plant receiving $\mathrm{FOL}$ to serve as pathogen control, T4 $=$ Plants receiving distilled sterilized water to serve as untreated control.

After 3 days of seedling transplantation, $50 \mathrm{ml}$ of $10 \mathrm{mM}$ ISR elicitor (Pure compound) was supplied to the tomato plants. After 2 days of treatment, FOL inoculum was provided @ $50 \mathrm{ml}$ of conidial suspension (see Fungal and Bacterial Strains). Plants were incubated under greenhouse conditions. Experiment was conducted twice having 15 plants in each replicate.

\section{Extraction of Plant Metabolites}

After 1 week of pathogen challenge to the seedlings plant metabolites were extracted. Leaf samples ( $1 \mathrm{~g})$ from young shoots were taken from treated and untreated plants separately. Samples were crushed in liquid nitrogen and the resulting powder was dissolved in $10 \mathrm{ml}$ of extraction solution comprising of methanol, chloroform and water mixed in a ratio of 80:10:10, respectively. Dissolved material was kept overnight at room temperature. Afterward metabolite extraction was done using micro filters.

\section{Derivatization}

Derivatization transforms a chemical compound into its derivative having similar chemical structure suitable for GC-MS analysis. Plant extract $(0.3 \mathrm{ml})$ was mixed with $0.1 \mathrm{ml}$ of ribitol (internal standard) inside a glass container. It was dried using $\mathrm{N}_{2}$ gas. After drying added $25 \mu \mathrm{l}$ of methoxyamine hydrochloride (MOX), mixed it and left overnight at room temperature. Afterward, $80 \mu \mathrm{l}$ of $N$-methyl- $N$ trimethylsilyltrifluoroacetamide (MSTFA) was supplied to the solution and left for $2 \mathrm{~h}$ at room temperature (Warth et al., 2014).

\section{GCMS Analysis of Derivatized Plant Metabolites}

Gas chromatography-mass spectrometry set up consisted of capillary column $(0.25 \mathrm{ID} \times 30 \mathrm{~m} \times 0.25 \mu \mathrm{m}$ film thicknesses $)$ and electron ionization was used as an ion source. Helium was used as a carrier gas at the flow rate of $1.0 \mathrm{ml} / \mathrm{min}$. Temperature of the capillary column was adjusted at $30^{\circ} \mathrm{C}$ for 3 min which was raised to $50^{\circ} \mathrm{C} / \mathrm{min}$ to $180^{\circ} \mathrm{C}$ and by $40^{\circ} \mathrm{C} / \mathrm{min}$ to $200^{\circ} \mathrm{C} / \mathrm{min}$. Derivatized plant extract was injected in GC-MS machine @ $1 \mu \mathrm{l}$.

\section{Plant Metabolites Analysis}

Metabolite analysis of tomato was performed using method devised by Lisec et al. (2006). Metabolite identification was carried out by comparing spectrum with NIST library. Levels of different metabolites were determined through Mzmine software package ${ }^{1}$; values obtained were log2-transformed (Steinfath et al., 2008) and normalized to show identical medium peak sizes per sample group. ClustVis ${ }^{2}$ online tool was used to make heatmap.

\section{Statistical Analysis}

The data was analyzed by performing ANOVA, and the significance of difference between the treatments was determined by DNMRT at $P<0.05$ using software DSASTAT (Onofri, 2007).

\section{RESULTS}

\section{Initial Screening of Metabolites Involved in ISR from Pseudomonas aeruginosa PM12}

Extracellular metabolites of $P$. aeruginosa (PM12) were found to be actively involved in suppressing Fusarium wilt of tomato under greenhouse conditions (Table 1). Significant reductions in the DI up to $73 \%$ were recorded in case of the extracellular metabolites that was almost equal to the efficacy of live cells, i.e., $75.86 \%$. Intracellular metabolites were not found capable in suppressing the disease to a significant level. Resultantly, it was concluded that extracellular metabolites are involved in disease suppression and contains ISR determinant/s (Figure 1).

\section{Searching of ISR Determinants from Extracellular Metabolites of Bacterial Strains}

In this experiment extracellular metabolites/CFCF of $P$. aeruginosa PM12 were examined for the presence of ISR determinant/s. Extraction of extracellular metabolites was done by using different organic solvents and then applied to the plants

\footnotetext{
${ }^{1} \mathrm{http}: / /$ mzmine.sourceforge.net/

${ }^{2}$ http://biit.cs.ut.ee/clustvis/
}

TABLE 1 | Preliminary screening of ISR determinant from $P$ aeruginosa PM12.

\begin{tabular}{llc}
\hline Treatments & Disease index & Biocontrol effect \\
\hline Live cells & $20.54^{\mathrm{D}}( \pm 1.82)$ & $71.17^{\mathrm{A}}( \pm 05.21)$ \\
Heat killed cells & $80.51^{\mathrm{B}}( \pm 6.54)$ & $11.67^{\mathrm{C}}( \pm 01.27)$ \\
Intra-cellular components & $79.23^{\mathrm{B}}( \pm 04.97)$ & $20.13^{\mathrm{B}}( \pm 01.88)$ \\
Extracellular metabolites & $22.88^{\mathrm{C}}( \pm 01.66)$ & $70.12^{\mathrm{A}}( \pm 06.47)$ \\
Pathogen control & $85.08^{\mathrm{A}}( \pm 0.792)$ & -
\end{tabular}

Capital letters represents levels of significance as governed by ANOVA and DNMRT at $(P>0.05)$. Values with \pm signs represent standard error between different replicates of same treatment. 


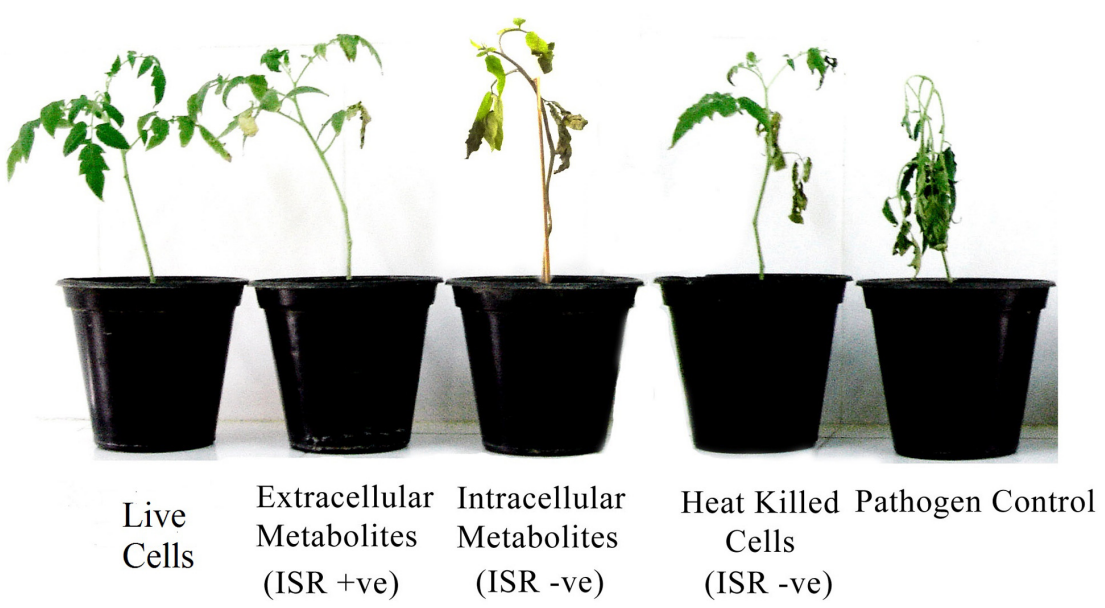

FIGURE 1 | Disease severity of tomato plants treated with Pseudomonas aeruginosa PM12 (live cells and heat treated cells), as well as with the intracellular and extracellular metabolites followed by Fusarium oxysporum challenge. Tomato plants shown are from 2 weeks of post-inoculation.

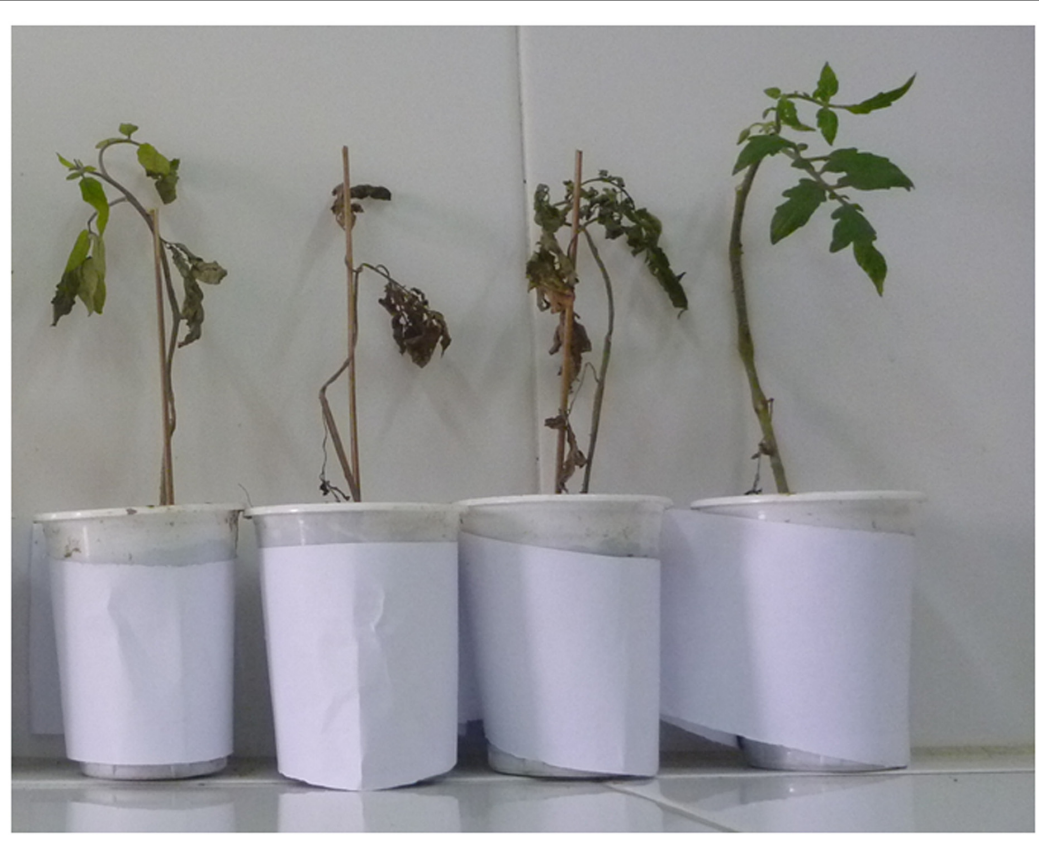

Chloroform Phase n-Hexane Phase n-Butanol Phase Ethyl acetate Phase

FIGURE 2 | Protective effect against Fusarium wilt symptoms of four solvent fractions from the extracellular metabolites secreted by $P$. aeruginosa (PM12).

as soil drench method and was challenged with the pathogen afterward. Compound/s present in ethyl acetate fraction of extracellular metabolites significantly reduced wilt disease in tomato plants when observed on visual grounds (Figure 2).

\section{Identification of ISR Determinant by GC/MS Analysis}

Ethyl acetate fraction of extracellular metabolites exhibiting maximum ISR activity was further processed via column chromatography using step wise elution method and ISR experiment was performed in a test tube assay. Sub-fraction showing maximum disease suppression was then analyzed through GC/MS. Chromatogram obtained from GC/MS analyses showed three peaks that were identified as 3-hydroxy-5-methoxy benzene methanol $(\mathrm{HMB})$, eugenol and tyrosine, respectively (Figure 3).

Biochemicals obtained were again tested for ISR activity in their pure form. The ISR bioassay showed that only HMB significantly $(P \leq 0.05)$ reduced disease severity to $76.25 \%$ 

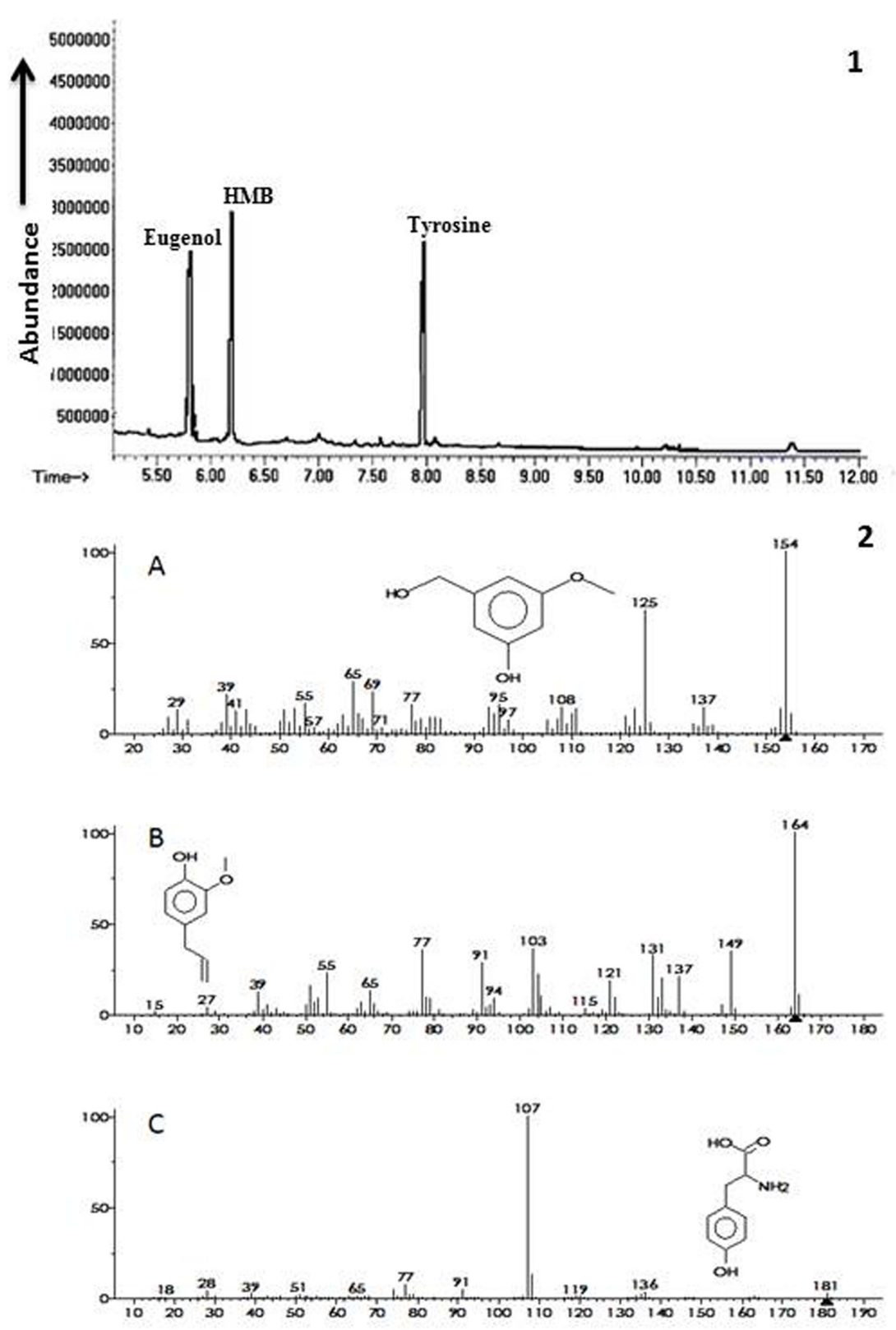

FIGURE 3 | Biochemicals observed in ISR active sub fraction found in extracellular metabolites of $\boldsymbol{P}$. aeruginosa (PM12). $1=$ Chromatogram obtained from Gas Chromatography and Mass Spectrometry (GC/MS) analysis for identification of ISR determinants. $2=$ lonization patterns of $A=3$-hydroxy-5-methoxy benzene methanol (HMB), B = Eugenol, $\mathrm{C}=$ Tyrosine.

at $10 \mathrm{mM}$ concentration. Whereas eugenol and tyrosine were not found efficient in reducing disease severity at the same concentration (Figure 4).

\section{Metablomic Analysis of Tomato Plants}

This study explored metabolic transitions observed in the tomato variety "Rio-Grande" under the stimulus of ISR elicitor (HMB) using GC/MS analysis. Whole metabolome of plants inoculated with $\mathrm{HMB}$ and pathogen in either combination were studied to elucidate ISR mechanism. In four different treatments, 94 metabolites were detected some of which were up regulated and some were down regulated as shown by different color schemes in heat map (Figure 5). Metabolite values obtained using Mzmine software were $\log 2$-transformed (Steinfath et al., 2008). Heat map was generated using online ClustVis tool with row wise scaling and correlation-based clustering. Most pronounced changes were depicted in metabolite levels of the plants receiving elicitor + pathogen making plants more resistant against pathogen attack by timely accumulation of defense related chemicals (Figure 5). Changes brought about in central metabolites 

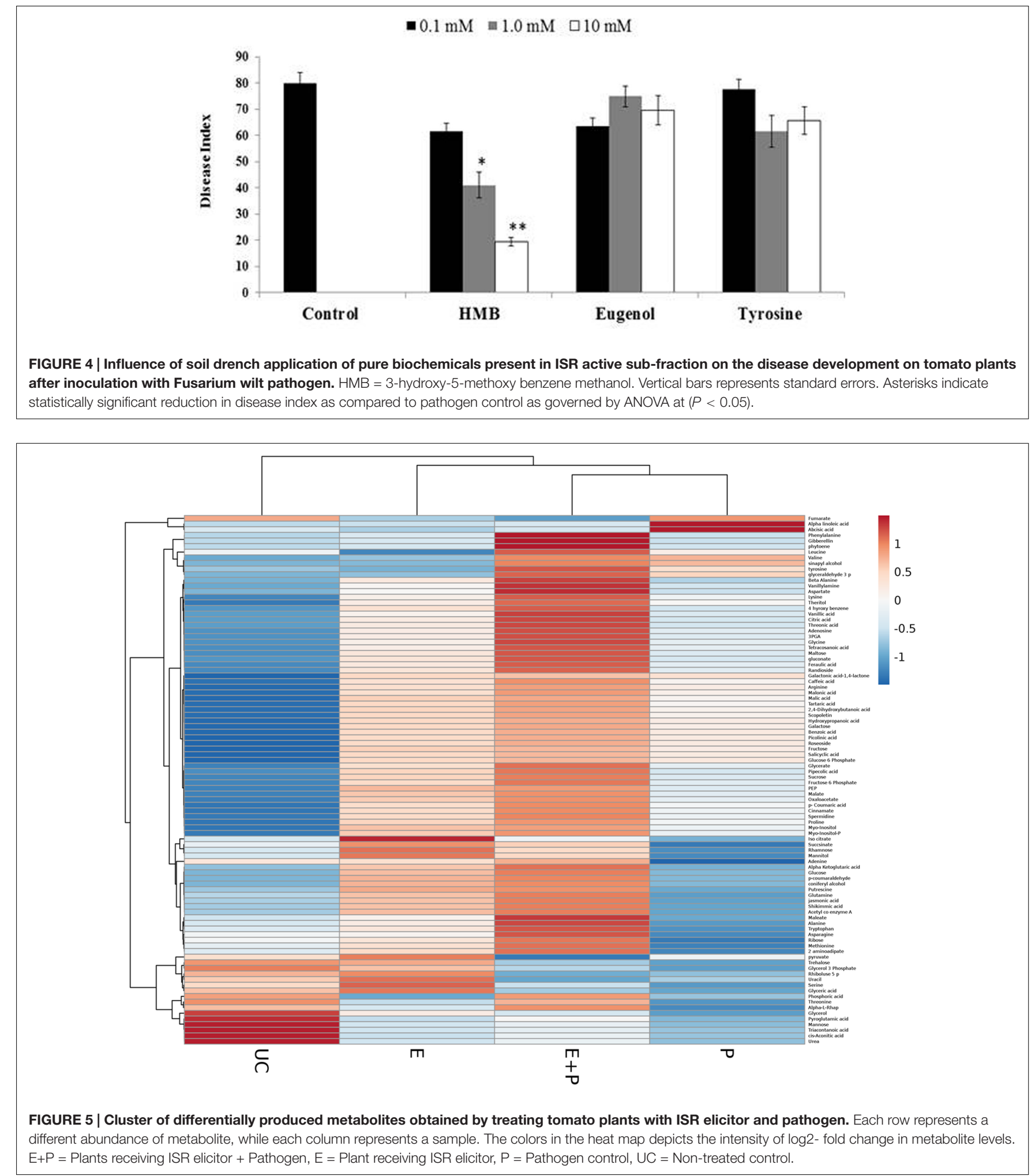

under the stimulus of different treatments were normalized to respective control and were expressed in fold change values. Most metabolic fluctuations were documented in primary and secondary metabolism, signaling and defense pathways.
Treatment receiving elicitor and pathogen showed variation in primary metabolism with different intensities. Upregulation of various metabolites involved in phenylpropanoid pathway was documented in case of the elicitor, e.g., 4-hydroxybenzene, 
cinnamate and tryptophan were increased to 3.19-, 2.31-, and 1.24-folds, respectively (Figure 5). Similarly plants treated with elicitor and pathogen significantly enhanced levels of most of the metabolites taking part in amino acid metabolism and TCA pathway (Figure 5). These findings illustrate that synergistic effect of the elicitor and the pathogen in inducing systemic resistance was more pronounced due to the active participation of the pathogen in some cases or elicitor in other.

Plants treated with the elicitor (HMB) showed enhanced levels of fructose, glucose and sucrose to 3.4-, 3.1-, and 1.2-folds, respectively. Whereas concentration of trehalose was found to be 0.9-fold less as compared to the untreated control (Figure 5).

In case of phosphorylated metabolites there was an increasing trend in the concentration of fructose-6- phosphate, glucose6-phosphate and myo-inositol-phosphate to 3.9-, 3.3-, and 1.9-folds, respectively. Whereas concentration of glycerol-3phosphate (0.9-fold) was decreased to 0.9 -fold in the presence of the elicitor in comparison to the untreated control.

Plants treated with the elicitor showed increased levels of organic acids including $\alpha$ ketoglutarate (2.7-fold), malate (2.8fold), oxaloacetate (2.3-fold), citrate (2.1-fold) and succinate (1.4fold). Whereas low levels of fumarate (0.4-fold) and cis- aconitate (0.3-fold) were recorded in comparison to the untreated control.

Elicitor treated plants also showed raised quantities of polyamines like picolinic acid (7.7-fold), pipecolic acid (4.7-fold), putrescine (2.8-fold), and spermidine (1.4-fold).

Amino acids like arginine, glutamine and proline levels were significantly increased to 3.04, 2.7 and 2.32-folds in case of the elicitor whereas leucine, tyrosine and threonine were decreased in comparison to the untreated control (Figure 5). Methionine acts as a precursor for ethylene biosynthesis through $S$-adenosyl methionine (SAM) (Bleecker and Kende, 2000). Methionine levels were significantly raised in plants under the influence of elicitor and elicitor + pathogen treatments.

Levels of salicylic acid were significantly upregulated in all the treatments in comparison to the untreated control. Plants treated with the elicitor and the pathogen showed increased levels of phenylalanine to 2.8-folds whereas application of the elicitor resulted in an increase of 1.2-folds as compared to the non-treated control. Metabolic pathways were drawn to show transitions in various metabolites in the presence of elicitor HMB (Figures 6-8). Metabolites belonging to the phenylpropanoid, glycolysis, photosynthesis and signal transduction pathways were significantly increased by the elicitor (HMB) in treated tomato plants.

Alterations in the metabolites of the plants receiving elicitor and elicitor + pathogen revealed that $\mathrm{HMB}$ elicitor from $P$. aeruginosa is responsible for inducing systemic resistance against Fusarium wilt in tomato.

\section{DISCUSSION}

\section{Isolating ISR Determinant(s) from Pseudomonas aeruginosa PM12}

Recent attempts in exploiting non-pathogenic rhizospheric microbes in biocontrol programs have shown their involvement as antagonists and plant defense stimulators. However, the exact nature of biochemicals imparting systemic resistance in plants against diseases remains poorly understood. This research was performed to isolate potential ISR determinant/s from $P$. aeruginosa (PM12) against F. oxysporum f. sp. lycopersici in tomato plant.

Pseudomonas aeruginosa PM12 is a non-pathogenic strain that was isolated from tomato rhizosphere. To avoid the use of whole bacterium as it is categorized as opportunistic pathogen we focused on the signal compound/s involved in eliciting defense mechanisms of the plant and identified the ISR determinant from extracellular metabolites of P. aeruginosa PM12. Moreover opportunistic pathogens are microbes that are capable of causing disease only in people who are immunocompromised or are otherwise especially susceptible. A critical issue concerns the pathogenic strains proposed for registration as biopesticides, since these strains are typically isolated from the environment, for example agricultural fields, rather than as clinical specimens. As such, these strains have no history of actually causing disease and may not be able to do so (GPO, 1999).

Extracellular metabolites and live cells of $P$. aeruginosa PM12 showed significant $(P \leq 0.05)$ protection against Fusarium wilt whereas the intracellular metabolites were unable to provide any considerable control (Table 1). The ethyl acetate fraction of extracellular metabolites of the bacterium exhibited maximum ISR activity and was sub fractioned using column chromatography. The active sub fraction was then analyzed through GC/MS. The chromatogram obtained identified three compounds, i.e., HMB, tyrosine and eugenol. Reconfirmation of active biochemical was achieved using pure compounds which revealed $\mathrm{HMB}$ as the most capable component in mitigating Fusarium wilt in tomato.

The elicitor compound, HMB, isolated from $P$. aeruginosa (PM12), is not yet reported for its biological activity against Fusarium wilt so this is the first finding describing its involvement in systemic resistance in tomato. Colonization of plant roots with $P$. fluorescens enhanced plant defenses against pathogen by sensitizing the plant through signal compounds (Verhagen et al., 2004). Literature showed the use of benzene in making pesticides, detergents, drugs, dyes, rubbers, explosives and lubricants (Ceresana, 2014). Furthermore antifungal and antimicrobial activity of poly substituted benzene derivatives has been reported. The substituent attached to the benzene ring and its position affects the activity of the compound against pathogen (Uyanik et al., 2009). Similarly elicitor benzothiazole isolated from Pseudomonas sp. has shown inhibition of mycelial growth and germination from ascospores and sclerotia of Sclerotinia sclerotiorum (Fernando et al., 2005). Aldehydes, ketones and benzenes from Bacillus amyloliquefaciens have been known to restrict mycelial growth and spore germination of F. oxysporum (Yuan et al., 2012). Bacterial volatile compounds help in maintaining plant health through ISR and production of antifungal compounds (Weisskopf, 2013). As benzene is involved in protection of plants against different pests so it is concluded that benzene is the actual molecule in elicitor compound $\mathrm{HMB}$ for imparting resistance against $\mathrm{FOL}$ in tomato. 


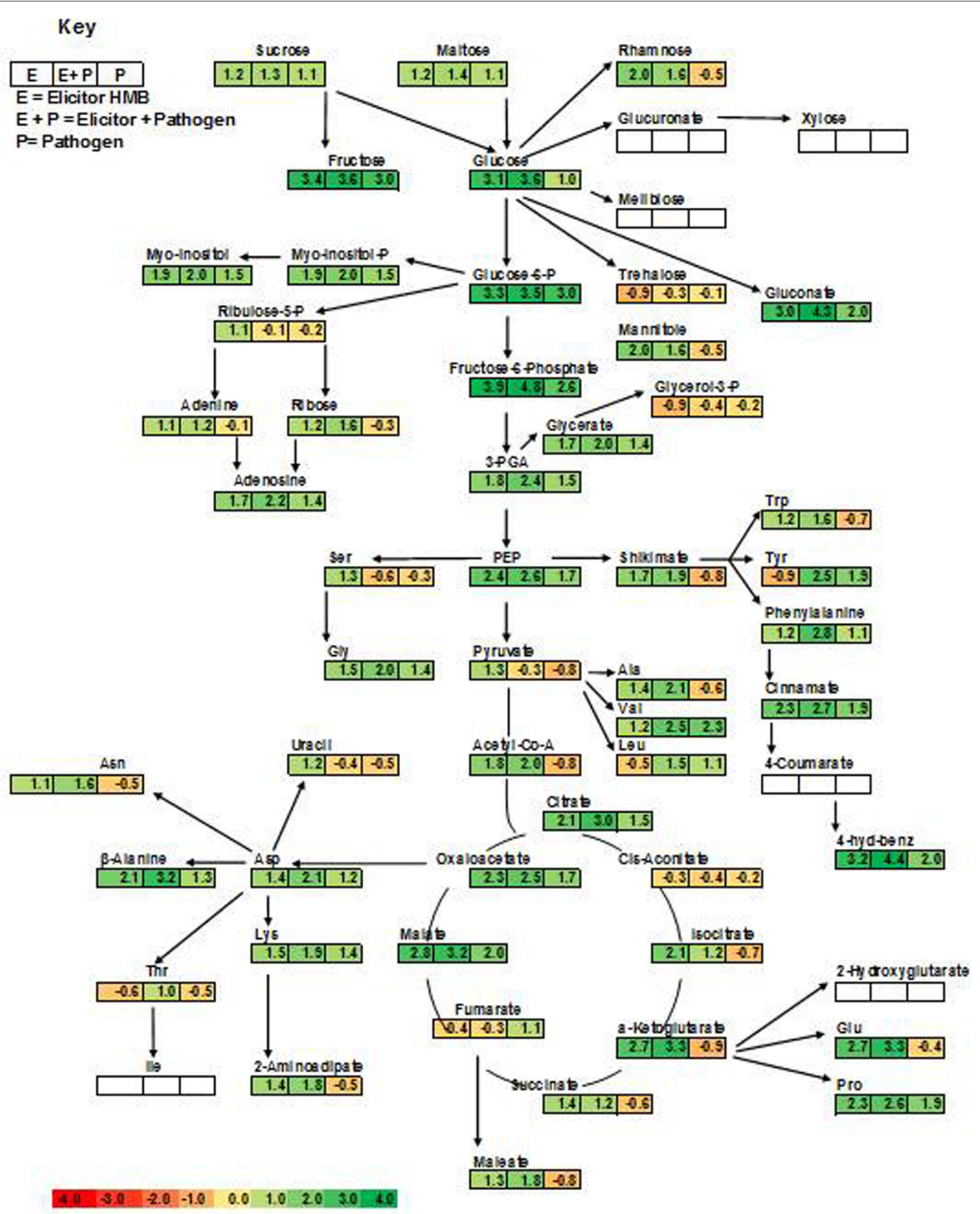

FIGURE 6 | Integration of the changes in the metabolites associated with selected metabolic pathways in the pathogen and elicitor-inoculated tomato plants at different combinations. The metabolites identified from the primary and secondary metabolic pathways are shown. Each square represents the $\log 2$ ratios of the abundance after 7 days of treatment applications. Fold values of all the treatments as compared to untreated control were used. Metabolites in green color show significant increase over control as governed by ANOVA at $P<0.05$. Red boxes represent no significant change as compared to control. White color represents metabolites that were not detected.

A considerable diversity of the elicitors involved in ISR has been observed in case of Pseudomonads. They include the building blocks of bacterial cells as well as extracellular compounds synthesized by the microbes (Jankiewicz and Kol-tonowicz, 2012). In current investigation HMB was discovered as an ISR determinant from $P$. aeruginosa PM12. Nowadays awareness regarding concept of immunity development in plants by the use of beneficial microbes is gaining momentum. In conventional agriculture system the identification of MAMPs from beneficial microbes and their 


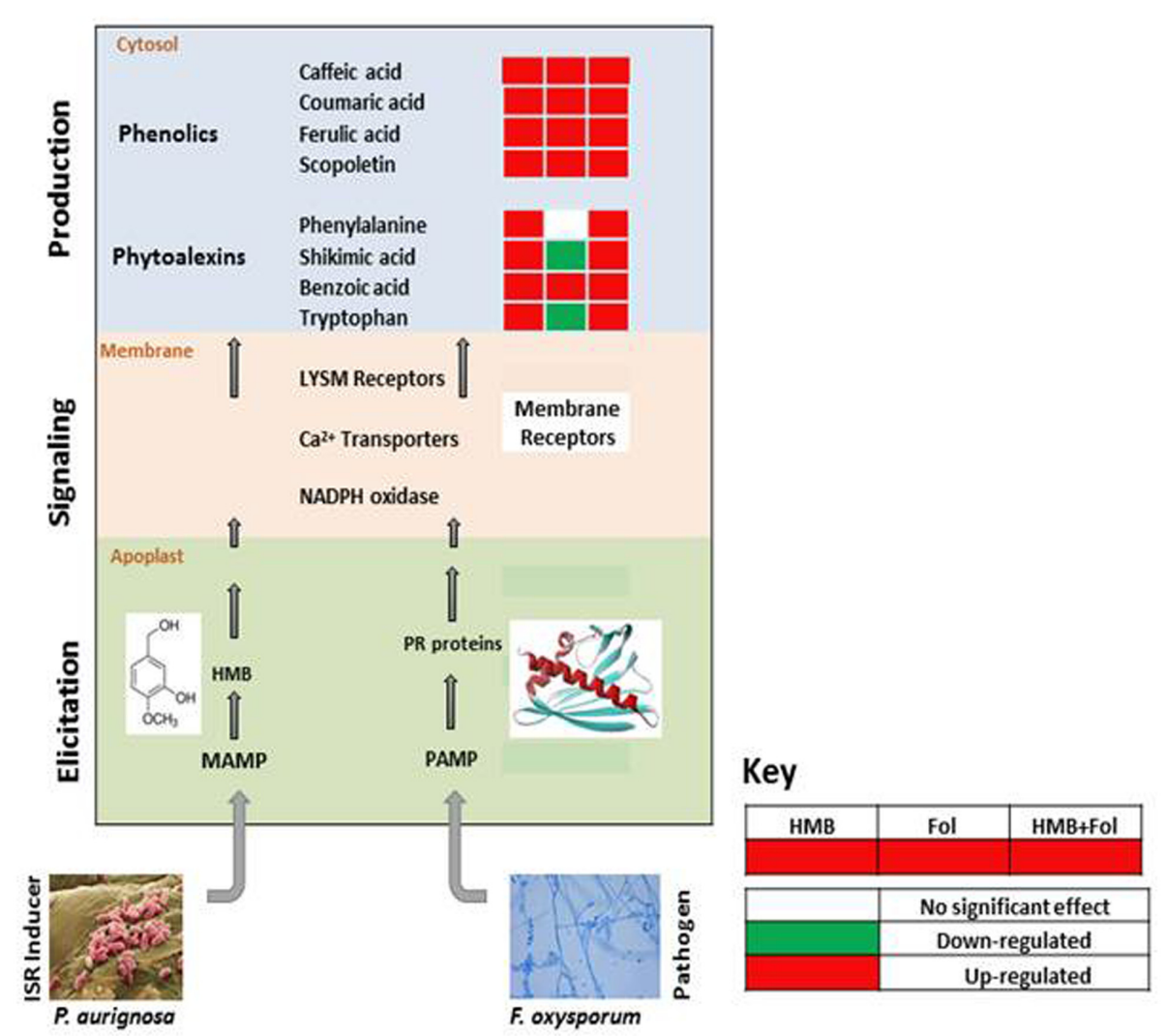

FIGURE 7 | Re-modulations in ISR signaling pathway of tomato plants induced by ISR elicitor (HMB) and Fusarium wilt pathogen in either combination.

use in formulation stimulates resistance in plants against pest attack.

Use of biocontrol agents in elicitation of resistance in plants is gaining importance these days. Some strains of Pseudomonas are clearly potent inducers of systemic resistance in plants (Van Wees et al., 1999; Meena et al., 2000).

\section{Mechanism behind Systemic Resistance Induced by Pseudomonas aeruginosa PM12 in Tomato Plants}

Biological inducers have been known to elicit metabolites involved in different pathways like pentose pathway, signaling transduction and tricarboxylic acid cyclic, etc. (Verhagen et al., 2004; Shoresh and Harman, 2008; Damodaran et al., 2010; Brotman et al., 2012). In second phase of this study heat map was developed to show variations in metabolites under the influence of HMB and accentuated in physiological pathways. In this investigation upregulation of metabolites involved in phenylpropanoid pathway may lead to resistance development in tomato plants treated with the elicitor HMB.

A significant decrease in fumaric acid was recorded in the elicitor and elicitor + pathogen treated plants. These results are in connection with the findings of Doornbos et al. (2009) who inoculated Arabidopsis plants with the PGP and ISR-inducing bacterium WCS358r and observed decrease in intermediates of Krebs cycle that showed an increased demand for carbon respiration.

Brotman et al. (2012) reported that putrescine induction by Trichoderma spp. was related to growth promotion in Arabidopsis thaliana. Polyamines were also involved in various defense responses (Tonon et al., 2004) similarly in this study upregulation of putrescine was noted.

In plant microbe interactions, sugars serve as signaling molecules for resistance induction against the pathogens and this resistance is termed as "sweet immunity" (Bolouri Moghaddam and Van den Ende, 2013). Like sucrose is involved in activating plant immune responses against pathogens (Tauzin and Giardina, 2014). Sucrose is known to trigger the production of isoflavonoids against $F$. oxysporum in lupine (Morkunas et al., 2011). Trehalose stimulates the activity of phenyl ammonia lyase and peroxidase against powdery mildew in wheat (Reignault et al., 2001). Fructose, sucrose and glucose elicited PR-protein transcripts in tobacco in a SAindependent pathway (Herbers et al., 1996). Moreover Kawano and Shimamoto (2013) and Yamaguchi et al. (2013) found that chitin is responsible for stimulation of Mitogen-Activated Protein Kinase (MAPK) cascade, lignin and phytoalexins production in rice. In this study significant increase in quantities of some carbohydrates like fructose, glucose, mannose, etc., were also 


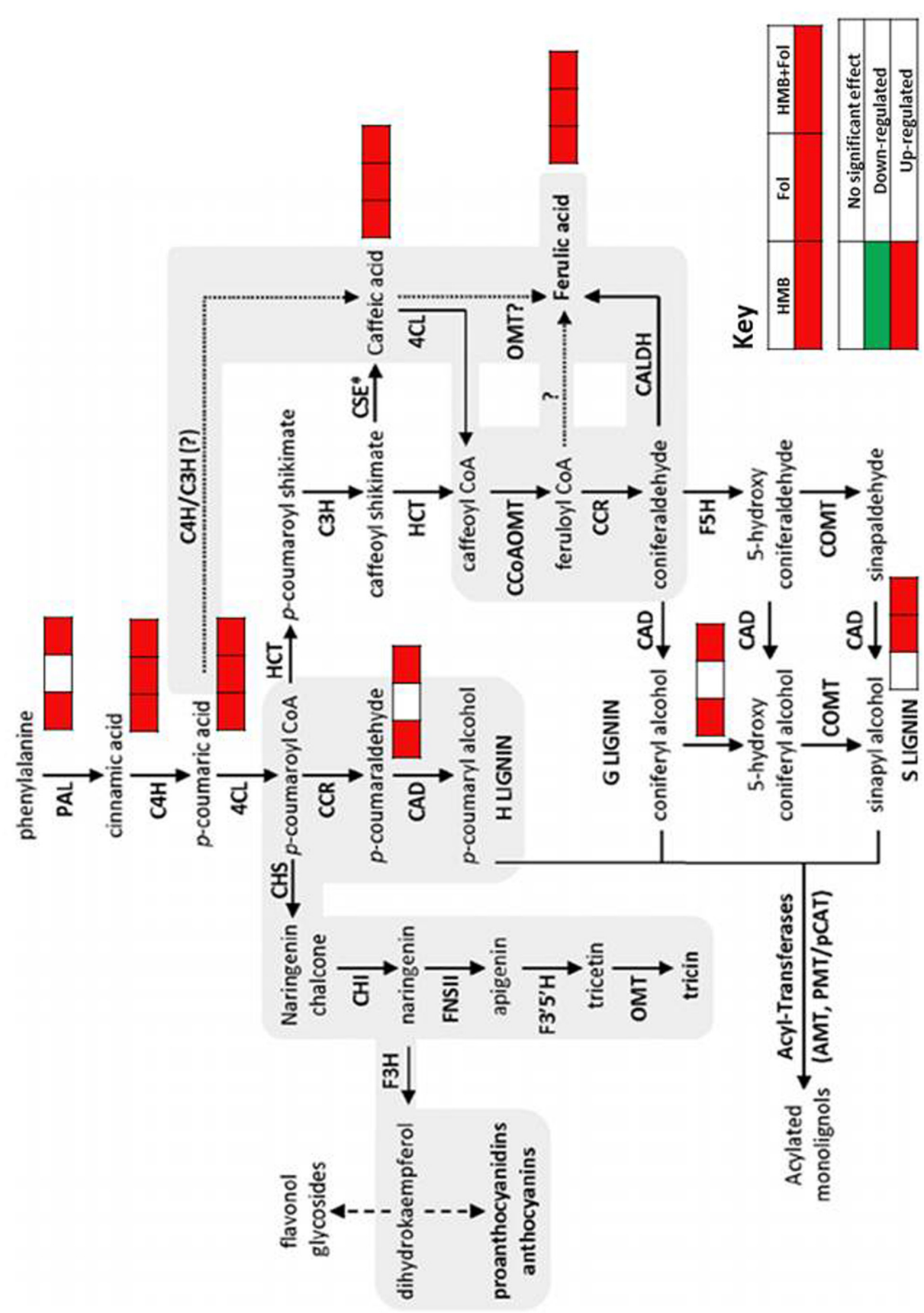

FIGURE 8 | Dynamics observed in phenylpropanoid pathway of tomato plants treated with ISR elicitor and F. oxysporum in either combination.

documented that are reportedly involve in plant growth and development.

Salicylic acid is involved in activation of defense responses in plants after challenging with a pathogen (Klessig et al., 2000). In a study enhanced levels of salicylic acid were documented when plants were challenged with pathogen or with P. fluorescens (Kumar and Sharma, 2013). Our results also showed upregulation of salicylic acid in the presence of the bacterial elicitor HMB.
Glutamate levels were significantly raised in treatments receiving the elicitor or elicitor and pathogen in combination. These results are in line with findings of Brotman et al. (2012). Glutamate acts as signaling compound in nitrogen signaling pathway (Forde and Lea, 2007).

Biochemicals like polyamines are involved in different physiological processes of the plants (Tonon et al., 2004). In this study plants primed with the elicitor (HMB) showed significant increase in polyamine levels. Likewise an increasing trend was 
also observed in organic acids in the $\mathrm{HMB}+$ pathogen treated plants. Shikimate pathway is stimulated by the synthesis of aromatic compounds which is responsible for defense response of plants (Tzin and Galili, 2010). Moreover shikimic acid concentration was also found to be enhanced under the effect of the bacterial elicitor HMB. Shikimic acid and malonic acid pathways are involved in phenolics synthesis leading to plant defense against pathogens. Phenolics include a variety of defense related compounds like anthocyanins, phytoalexins, flavonoids, furanocoumarins tannins and lignin (Freeman and Beattie, 2008). Present study illustrated the significance of metabolic dynamics engaged in defense mechanisms of the tomato plants infected with $F$. oxysporum ensured triggering of ISR by the bacterial elicitor HMB.

Phenylpropanoids like lignin, phytoalexins, flavonoids, tannins, etc., are the secondary metabolites of the plants produced under stress conditions (Vogt, 2010). They provide resistance in plants against phytopathogens through accumulation of lignin that acts as a barrier for penetration in plant tissues. Enzymes involved in phenylpropanoid pathways viz; PPO, $\mathrm{PO}$ and PAL impart rigidity and mechanical strength to the plant cell walls through production of lignin metabolites that act as barrier for invading fungal pathogens (Mohammadi and Kazemi, 2002; Anjum et al., 2012). Metabolic dynamics engaged in defense mechanisms of the tomato plants infected with F. oxysporum ensured elicitation of ISR by the bacterial elicitor HMB. Enhanced metabolite upregulation under influence of the elicitor + pathogen treatment may be due to the synergistic effect of ISR and SAR that may lead to better cope with the stress condition of the plant by activation of defense machinery.

\section{REFERENCES}

Agrios, G. N. (2005). Plant Pathology, 5th Edn. Amsterdam: Elsevier Academic Press, 922.

Algam, A. S., Guan-Lin, X., and Coosemans, J. (2005). Delivery methods for introducing endophytic Bacillus into tomato and their effect on growth promotion and suppression of tomato wilt. Plant Pathol. J. 4, 69-74. doi: 10.3923/ppj.2005.69.74

Anjum, T., Fatima, S., and Amjad, S. (2012). Physiological changes in wheat during development of loose smut. Trop. Plant Pathol. 37, 102-107.

Bakker, P. A. H. M., Pieterse, C. M. J., and van Loon, L. C. (2007). Induced systemic resistance by fluorescent Pseudomonas spp. Phytopathology 97, 239-243. doi: 10.1094/PHYTO-97-2-0239

Benhamou, N., Belanger, R. R., and Paulitz, T. (1996a). Ultrastructural and cytochemical aspects of the interaction between Pseudomonas flourescens and $\mathrm{Ri} \mathrm{T}-\mathrm{DNA}$ transformed pea roots: host response to colonization by Pythium ultimum Trow. Planta 199, 105-117. doi: 10.1007/BF001 96887

Benhamou, N., Kloepper, J. W., Quadt-Hallmann, A., and Tuzun, S. (1996b). Induction of defense-related ultrastructural modifications in pea root tissues inoculated with endophytic bacteria. Physiol. Plant Pathol. 112, 919-929.

Bhattacharyya, P. N., and Jha, D. K. (2012). Plant growth-promoting rhizobacteria (PGPR): emergence in agriculture. World J. Microbiol. Biotechnol. 28, 1327-1350. doi: 10.1007/s11274-011-0979-9

Bleecker, A. B., and Kende, H. (2000). Ethylene: a gaseous signal molecule in plants. Annu. Rev. Cell. Dev. Biol. 16, 1-18. doi: 10.1146/annurev.cellbio.16.1.1

Bolouri Moghaddam, M. R., and Van den Ende, W. (2013). Sugars, the clock and transition to flowering. Front. Plant Sci. 4:22. doi: 10.3389/fpls.2013.00022

\section{CONCLUSION}

Findings of our study revealed that priming of plant roots with $P$. aeruginosa helps in suppressing Fusarium wilt by releasing an ISR elicitor HMB. Furthermore this elicitor compound is engaged in elicitation of defense mechanisms in tomato plants through metabolic transitions that leads to resistance induction against Fusarium wilt pathogen. Research regarding targeting of genes controlling the regulation of this elicitor compound will undoubtedly help in pest management practices in a sustainable manner.

\section{AUTHOR CONTRIBUTIONS}

SF and TA designed the study. TA revised the manuscript critically. All authors read and approved the final version of the manuscript.

\section{ACKNOWLEDGMENT}

We are thankful to Forman Christian College, Lahore, Pakistan for providing us assistance in GC/MS analysis.

\section{SUPPLEMENTARY MATERIAL}

The Supplementary Material for this article can be found online at: http://journal.frontiersin.org/article/10.3389/fpls.2017.00848/ full\#supplementary-material

Brotman, Y., Lisec, J., Meret, M., Chet, I., Willmitzer, L., and Viterbo, A. (2012). Transcript and metabolite analysis of the Trichoderma-induced systemic resistance response to Pseudomonas syringae in Arabidopsis thaliana. Microbiology 158, 139-146. doi: 10.1099/mic.0.052621-0

Cachinero, J. M., Hervas, A., Jimenez-Diaz, R. M., and Tena, M. (2002). Plant defence reactions against Fusarium wilt in chickpea induced by incompatible race 0 of Fusarium oxysporum $\mathrm{f}$. sp. ciceris and non host isolates of F. oxysporum. Plant Pathol. 51, 765-776. doi: 10.1046/j.1365-3059.2002. 00760.x

Ceresana (2014). Market Study: Benzene, 2nd Edn. Available at: http://www. ceresana.com/en/market-studies/chemicals/benzene/

Choudhary, D. K. (2011). Plant growth-promotion (PGP) activities and molecular characterization of rhizobacterial strains isolated from soybean (Glycine max L. Merril) plants against charcoal rot pathogen, Macrophomina phaseolina. Biotechnol. Lett. 33, 2287-2295. doi: 10.1007/s10529-011-0699-0

Damodaran, P. N., Udaiyan, K., and Jee, H. J. (2010). Biochemical changes in cotton plants by arbuscular mycorrhizal colonization. Res. Biotechnol. 1, 6-14.

De Vleesschauwer, D., and Höfte, M. (2009). Rhizobacteria-induced systemic resistance. Adv. Bot. Res. 51, 223-281. doi: 10.1016/S0065-2296(09)51006-3

De Vos, R. C., Moco, S., Lommen, A., Keurentjes, J. J., Bino, R. J., and Hall, R. D. (2007). Untargeted large-scale plant metabolomics using liquid chromatography coupled to mass spectrometry. Nat. Protocols 2, 778-791. doi: 10.1038/nprot.2007.95

Doornbos, R., Scwachtje, J., Van Dongen, J. T., Karojet, S., Erban, A., Kopka, J., et al. (2009). "Root colonization and induction of systemic resistance by fluorescent Pseudomonas spp. in Arabidopsis: effect on primary metabolites in the leaves," in Analysis of Rhizosphere Bacterial Communities in Arabidopsis: Impact of Plant Defense Signaling. Ph.D thesis, (Utrecht: Utrecht University), 67-80. 
Epp, D. (1987). "Somaclonal variation in banana: a case study with Fusarium wilt," in Banana and Plantain Breeding Strategies, eds G. J. Persley and E. A. De Langhe (Canberra, ACT: ACIAR Publication).

FAO (2013). FAOSTAT. Food and Agriculture Organization of the United Nations. Available at: http://faostat.fao.org/default.aspx

Fatima, S., and Anjum, T. (2016). Induction of systemic resistance in tomato by Pseudomonas aeruginosa PM12 against Fusarium wilt. Pak. J. Biotechnol. 13, 117-124.

Fatima, S., and Anjum, T. (2017). Potential of rhizospheric Pseudomonas strains to manage Fusarium wilt of tomato. J. Agric. Res. 55.

Fernando, W. G. D., Ramarathnam, R., Krishnamoorthy, A. S., and Savchuk, S. C. (2005). Identification and use of potential bacterial organic antifungal volatiles in biocontrol. Soil Biol. Biochem. 37, 955-964. doi: 10.3389/fmicb.2015. 01056

Forde, B. G., and Lea, P. J. (2007). Glutamate in plants: metabolism, regulation, and signaling. J. Exp. Bot. 58, 2339-2358. doi: 10.1093/jxb/erm121

Fravel, D. R., Deahl, K. L., and Stomme, J. R. (2005). Compatibility of the biocontrol fungus Fusarium oxysporum strain CS-20 with selected fungicides. Biol. Control. 34, 165-169. doi: 10.1016/j.biocontrol.2005.04.007

Freeman, B. C., and Beattie, G. A. (2008). An Overview of Plant Defenses Against Pathogens and Herbivores. Available at: http://www.apsnet.org/edcenter/ intropp/topics/Pages/OverviewOfPlantDiseases.aspx

Glick, B. R. (2012). Plant Growth-Promoting Bacteria: Mechanisms and Applications. Waterloo, ON: Hindawi Publishing Corporation, Scientifica.

GPO (1999). Authenticated US government information. Federal Register 66.

Haas, D., and Défago, G. (2005). Biological control of soil-borne pathogens by fluorescent Pseudomonads. Nat. Rev. Microbiol. 3, 307-319. doi: 10.1038/ nrmicro1129

Henry, G., Thonart, P., and Ongena, M. (2012). PAMPs, MAMPs, DAMPs and others: an update on the diversity of plant immunity elicitors. Biotechnol. Agron. Soc. Environ. 16, 257-268.

Herbers, K., Meuwly, P., Frommer, W. B., Metraux, J. P., and Sonnewald, U. (1996). Systemic acquired resistance mediated by the ectopic expression of invertase: possible hexose sensing in the secretory pathway. Plant Cell 8, 793-803. doi: $10.1105 /$ tpc.8.5.793

Jankiewicz, U., and Kol-tonowicz, M. (2012). The involvement of Pseudomonas bacteria in induced systemic resistance in plants (review). Appl. Biochem. Microbiol. 48, 244-249. doi: 10.1134/S0003683812030052

Jones, J. D., and Dangl, J. L. (2006). The plant immune system. Nature 444, 323-329. doi: 10.1038/nature05286

Kawano, Y., and Shimamoto, K. (2013). Early signaling network in rice PRRmediated and R-mediated immunity. Curr. Opin. Plant. Biol. 16, 496-504. doi: 10.1016/j.pbi.2013.07.004

Klessig, D. F., Durner, J., Noad, R., Navarre, D. A., Wendehenne, D., Kumar, D., et al. (2000). Nitric oxide and salicylic acid signaling in plant defense. Proc. Nat. Acad. Sci. U.S.A. 97, 8849-8855. doi: 10.1073/pnas.97.16. 8849

Kumar, S., and Sharma, S. (2013). Metabolites change in Jatropha plants due to seed treatment with rhizobacteria and Rhizoctonia bataticola. Annu. For. Res. 56, 389-396.

Lisec, J., Schauer, N., Kopka, J., Willmitzerm, L., and Fenie, A. R. (2006). Gas chromatography mass spectrometry based metabolite profiling in plants. Nat. Protoc. 1, 387-396. doi: 10.1038/nprot.2006.59

Liu, L., Kloepper, J. W., and Tuzun, S. (1995). Induction of systemic resistance in cucumber against Fusarium wilt by plant growth-promoting rhizobacteria. Phytopathology 85, 695-698. doi: 10.1094/Phyto-85-695

Lucas, J. A. (2011). Advances in plant disease and pest management. J. Agri. Sci. 149, 91-114. doi: 10.1017/S0021859610000997

Lugtenberg, B., and Kamilova, F. (2009). Plant-growth-promoting rhizobacteria. Annu. Rev. Microbiol. 63, 541-555. doi: 10.1146/annurev.micro.62.081307. 162918

Maffei, M. E., Arimura, G. I., and Mithoefer, A. (2012). Natural elicitors, effectors and modulators of plant responses. Nat. Prod. Rep. 29, 1288-1303. doi: 10.1039/ c2np20053h

Meena, B., Radhajeyalakshmi, R., Murimuthu, T., Vidhyasekran, P., Doraiswami, S., and Veilazhahan, R. (2000). Induction of pathogenesis related proteins, phenolics and phenylalanine ammonia lyase in groundnut by P. fluorescens. J. Plant Dis. Prot. 107, 514-527.
Miller, E. C., Hadley, C. W., Schwartz, S. J., Erdman, J. W., Boileau, T. W. M., and Clinton, S. K. (2002). Lycopene, tomato products, and prostate cancer prevention. Have we established causality? Pure Appl. Chem. 74, 1435-1441.

Mohammadi, M., and Kazemi, H. (2002). Changes in peroxidase and polyphenol oxidase activities in susceptible and resistant wheat heads inoculated with Fusarium graminearum and induced resistance. Plant Sci. 162, 491-498. doi: 10.1016/S0168-9452(01)00538-6

Morkunas, I., Narozna, D., Nowak, W., Samardakiewicz, S., and RemleinStarosta, D. (2011). Cross-talk interactions of sucrose and Fusarium oxysporum in the phenylpropanoid pathway and the accumulation and localization of flavonoids in embryo axes of yellow lupine. J. Plant Physiol. 168, 424-433. doi: 10.1016/j.jplph.2010.08.017

Newman, M. A., Sundelin, T., Nielsen, J. T., and Erbs, G. (2013). MAMP (microbe associated molecular pattern) triggered immunity in plants. Front. Plant Sci. 4:139. doi: 10.3389/fpls.2013.00139

Onofri, A. (2007). "Routine statistical analyses of field experiments by using an Excel extension," in Proceedings 6th National Conference Italian Biometric Society: La statistica nelle scienze della vita e dell'ambiente, Pisa, 93-96.

Park, M. S., Jang, K. S., Choi, Y. H., Kim, J. C., and Choi, G. J. (2013). Simple Mass-screening methods for resistance of tomato to Fusarium oxysporum $\mathrm{f}$. sp. lycopersici. Korean J. Hortic. Sci. Technol. 31, 110-116. doi: 10.7235/hort.2013. 12134

Pieterse, C. M. J., Zamioudis, C., Berendsen, R. L., Weller, D. M., Van Wees, S. C. M., and Bakker, P. A. H. M. (2014). Induced systemic resistance by beneficial microbes. Annu. Rev. Phytopathol. 52, 347-375. doi: 10.1146/ annurev-phyto-082712-102340

Pottorf, L. (2006). Recognizing Tomato Problems. Fort Collins, CO: Colorado State University cooperative Extension, 949.

Reignault, P., Cogan, A., Muchembled, J., Sahraoui, A. L. H., Durand, R., and Sancholle, M. (2001). Trehalose induces resistance to powdery mildew in wheat. New Phytol. 149, 519-529. doi: 10.1094/PHYTO-07-13-0191-R

Shoresh, M., and Harman, G. E. (2008). The molecular basis of shoot responses of maize seedlings to Trichoderma harzianum T22 inoculation of the root: a proteomic approach. Plant Physiol. 147, 2147-2163. doi: 10.1104/pp.108. 123810

Steinfath, M., Groth, D., Lisec, J., and Selbig, J. (2008). Metabolite profile analysis: from raw data to regression and classification. Physiol. Plant. 132, 150-161. doi: 10.1111/j.1399-3054.2007.01006.x

Sumayo, M., Hahm, M. S., and Ghim, Y. (2013). Determinants of plant growth-promoting Ochrobactrum lupini KUDC1013 involved in induction of systemic resistance against Pectobacterium carotovorum subsp. carotovorum in Tobacco Leaves. Plant Pathol. J. 29, 174-181. doi: 10.5423/PPJ.SI.09. 2012.0143

Tauzin, A. S., and Giardina, T. (2014). Sucrose and invertases, a part of the plant defence response to the biotic stresses. Front. Plant Sci. 5:293. doi: 10.3389/fpls. 2014.00293

Thordal-Christensen, H. (2003). Fresh insights into processes of nonhost resistance. Curr. Opin. Plant Biol. 6, 351-357. doi: 10.1016/S1369-5266(03) 00063-3

Tonon, G., Kevers, C., Faivre-Rampant, O., Graziani, M., and Gaspar, T. (2004). Effect of $\mathrm{NaCl}$ and mannitol iso-osmotic stresses on proline and free polyamine levels in embryogenic Fraxinus angustifolia callus. J. Plant Physiol. 161, 701-708. doi: 10.1078/0176-1617-01096

Tzin, V., and Galili, G. (2010). New insights into the shikimate and aromatic amino acids biosynthesis pathways in plants. Mol. Plant 3, 956-972. doi: 10.1093/mp/ ssq048

Underwood, W. (2012). The plant cell wall: a dynamic barrier against pathogen invasion. Front. Plant Sci. 3:85. doi: 10.3389/fpls.2012.00085

United States Department of Agriculture [USDA] (2009). Tomatoes (Red, Ripe, Raw, Year Round Average) - Nutrient Values and Weights for Edible Portion (NDB No. 11529). USDA National Nutrient Database for Standard Reference, Release 22. Available at: https://ndb.nal.usda.gov/ndb/foods/show/3225? $\mathrm{fgcd}=\& \mathrm{manu}=\& \mathrm{lface} t=\&$ format $=\& \operatorname{count}=\& \max =50 \&$ offset $=\&$ sort $=$ default $\&$ order $=$ asc \&qlookup $=$ tomato $\& \mathrm{ds}=\& \mathrm{q}=\& \mathrm{qp}=\& \mathrm{qa}=\& \mathrm{qn}=\& \mathrm{q}=\&$ ing $=\quad$ [accessed December 31, 2009].

Uyanik, A., Oktemer, A., and Logoglu, E. (2009). Antimicrobial and antifungal activity study of poly substituted benzene derivatives. Commun. Fac. Sci. Univ. Ank. 55, 17-22. 
Van Peer, R., Niemann, G. J., and Schippers, B. (1991). Induced resistance and phytoalexin accumulation in biological control of Fusarium wilt of carnation by Pseudomonas sp strain WCS 417r. Phytopathology 81, 728-734. doi: 10.1094/ Phyto-81-728

Van Wees, S. C. M., Luijendijk, M., Smoorehburg, I., Van, L. L. C., and Pieterse, C. M. J. (1999). Rhizobacteria mediated induced systemic resistance (ISR) in Arabidopsis is not associated with a direct effect of expression of known defence related gene but stimulates the expression of jasmonate induced gene upon challenge. Plant Mol. Biol. 41, 537-549. doi: 10.1023/A:1006319216982

Verhagen, B. W., Glazebrook, J., Zhu, T., Chang, H. S., Van Loon, L. C., and Pieterse, C. M. (2004). The transcriptome of rhizobacteria-induced systemic resistance in Arabidopsis. Mol Plant Microbe Interact. 17, 895-908. doi: 10.1094/ MPMI.2004.17.8.895

Verhagen, B. W. M., TrotelAziz, P., Couderchet, M., Höfte, M., and Aziz, A. (2010). Pseudomonas spp.-induced systemic resistance to Botrytis cinerea is associated with induction and priming of defence responses in grapevine. J. Exp. Bot. 61, 249-260. doi: 10.1093/jxb/erp295

Vogt, T. (2010). Phenylpropanoid biosynthesis. Mol. Plant 3, 2-20. doi: 10.1093/ $\mathrm{mp} / \mathrm{ssp} 106$

Walters, D. R., Ratsep, J., and Havis, N. D. (2013). Controlling crop diseases using induced resistance: challenges for the future. J. Exp. Bot. 64, 1263-1280. doi: $10.1093 /$ jxb/ert026

Warth, B., Parich, A., Bueschl, C., Schoefbeck, D., Neumann, N. K. N., Kluger, B., et al. (2014). GC-MS based targeted metabolic profiling identifies changes in the wheat metabolome following deoxynivalenol treatment. Metabolomics 14, 731-741.

Weisskopf, L. (2013). "The potential of bacterial volatiles for crop protection against phytophathogenic fungi," in Microbial Pathogens and Strategies for
Combating them: Science, Technology and Education, ed. A. M. éndez-Vilas (Badajoz: Formatex Research Center), 1352-1363.

Yamaguchi, K., Yamada, K., Ishikawa, K., Yoshimura, S., Hayashi, N., Uchihashi, K., et al. (2013). A receptor-like cytoplasmic kinase targeted by a plant pathogen effector is directly phosphorylated by the chitin receptor and mediates rice immunity. Cell Host Microbe. 13, 347-357. doi: 10.1016/j.chom.2013. 02.007

Yuan, J., Raza, W., Shen, Q. R., and Huang, Q. W. (2012). Antifungal Activity of Bacillus amyloliquefaciens NJN-6 volatile compounds against Fusarium oxysporum f. sp cubense. Appl. Environ. Microbiol. 78, 5942-5944. doi: 10.1128/ AEM.01357-12

Zdor, R. E., and Anderson, A. J. (1992). Influence of root colonizing bacteria on the defense responses of bean. Plant Soil 140, 99-107. doi: 10.1007/BF00012811

Zhao, Y., Zhao, J., Zhao, C., Zhou, H., Li, Y., Zhang, J., et al. (2015). A metabolomics study delineating geographical location-associated primary metabolic changes in the leaves of growing tobacco plants by GC-MS and CE-MS. Sci. Rep. 5:16346. doi: $10.1038 /$ srep 16346

Conflict of Interest Statement: The authors declare that the research was conducted in the absence of any commercial or financial relationships that could be construed as a potential conflict of interest.

Copyright (c) 2017 Fatima and Anjum. This is an open-access article distributed under the terms of the Creative Commons Attribution License (CC BY). The use, distribution or reproduction in other forums is permitted, provided the original author(s) or licensor are credited and that the original publication in this journal is cited, in accordance with accepted academic practice. No use, distribution or reproduction is permitted which does not comply with these terms. 